\title{
Effect of timing and intensity of grazing on the herbage quality of a Mediterranean rangeland
}

\author{
Z. Henkin ${ }^{1,2,5}$, S.Y. Landau², E.D. Ungar ${ }^{2}$, A. Perevolotsky², \\ Y. Yehuda ${ }^{3}$ and M. Sternberg ${ }^{4}$ \\ ${ }^{1}$ Beef Cattle Section, Newe-Ya'ar Research Center, Department of Natural Resources, \\ Agricultural Research Organization \\ P.O. Box 1021, Ramat Yishay, 30095, Israel \\ ${ }^{2}$ Department of Agronomy and Natural Resources, \\ Agricultural Research Organization - the Volcani Center \\ P.O. Box 6, Bet Dagan 50250, Israel \\ ${ }^{3}$ MIGAL - Galilee Technological Center \\ P.O. Box 831, Kiryat Shemona 11016, Israel \\ ${ }^{4}$ Department of Plant Sciences, Wise Faculty of Life Sciences, Tel Aviv University \\ Tel Aviv 69978, Israel
}

\begin{abstract}
The main objective of this study was to determine the quality of herbage grazed by cattle in hilly Mediterranean grassland under different grazing management systems. The study was conducted at the Karei Deshe experimental farm, located in eastern Galilee (Israel), between the 2003 and 2005 grazing seasons. Treatments comprised stocking rates of 0.9 and 1.8 ha per cow, and systems of continuous and seasonal (early vs late) grazing. Herbage was sampled at four periods during each grazing season. Samples were analysed for digestibility, protein, ADF, NDF and ash contents using near infrared reflectance spectroscopy. Significant differences in herbage quality were found between periods, years and their interaction. Herbage quality in paddocks grazed continuously or early in the season was significantly higher than in those grazed late in the season. Stocking rate had a relatively minor effect on herbage quality.
\end{abstract}

KEY WORDS: herbage quality, grazing intensity, Mediterranean rangeland

\section{INTRODUCTION}

Diet quality and availability are most important factors in management of grazing systems; they directly affect animal condition which is dependent on

\footnotetext{
${ }^{5}$ Corresponding author: e-mail: henkinz@volcani.agri.gov.il
} 
the grazed area. Animal nutrition controls landscape management, as low forage quality can decrease energy expenditure. Stocking rate may affect available forage quality and mass, forcing cattle to modify diet and habitat selection. Low forage quality during the hot and dry season and/or high stocking rate could increase stress which would have a negative impact on animal health. The timing of grazing can also have a strong influence on herbage quality: continuous or early grazing may be important to maintain younger herbage of relatively high quality. Nutritional value of grasslands has an important role on cattle productivity and the management of grazing ruminants for sustainability of vegetation in rangeland. Optimizing grazing management for higher performance of animal production and for rangeland sustainability is an important goal, and the quality of the herbage is an important factor in these systems. The aim of this research was to study effects of stocking rate and seasonality of grazing on herbage quality in order to improve cattle management systems.

\section{MATERIAL AND METHODS}

The study was conducted at the Karei Deshe experimental farm, located in the eastern Galilee in the north-east of Israel (long. 35 $35^{\prime} \mathrm{E}$; lat. $32^{\circ} 55^{\prime} \mathrm{N}$; alt. $60-250 \mathrm{~m}$ a.s.1.). The site is described in detail in Gutman et al. $(1990,1999)$. The topography is hilly, with slopes generally less than $20^{\circ}$ (Seligman et al., 1989) covered with basaltic rocks with an average cover of 30\% (Gutman and Seligman, 1979). The soil is a fertile brown basaltic protogrumosol of variable depth, but seldom deeper than $60 \mathrm{~cm}$. The area has a Mediterranean climate, characterized by wet and mild winters with mean minimum and maximum temperatures of $7^{\circ} \mathrm{C}$ and $14^{\circ} \mathrm{C}$, respectively. The average seasonal rainfall is $570 \mathrm{~mm}$, falling mostly in winter. The rainy season begins in October-November and ends in April. The vegetation is a rich hemicryptophytic grassland (Zohary, 1973) dominated by Hordeum bulbosum L., Echinops spp., Psoralea bituminosa L. and many annual species.

The study took place in twelve paddocks of 14 to 28 ha each. Treatments comprised two stocking rates ( 0.9 and 1.8 ha per cow) and three forms of grazing management (continuous (C), seasonal early (E) and seasonal late (L)), with two replicates for each treatment. The paddocks were grazed during 2003 - 2005 from January- February to August-October.

Sampling took place every year between 2003 and 2005 at four different periods: a. winter - beginning of grazing (January-February), b. spring - maximum vegetation growth (April), c. early summer (June), d. end of summer (AugustSeptember). Quadrats of $25 \times 25 \mathrm{~cm}$ were randomly placed along permanent transects that crossed all different paddocks and above-ground herbaceous biomass was harvested down to ground level. Twenty samples were harvested 
in each paddock at each of the periods, totaling 960-1.020 samples each year of the study. The harvested plant material was oven-dried at $65^{\circ} \mathrm{C}$ and weighed. Samples from each paddock were grouped into three replicates and were then ground and analysed for digestibility, protein, ADF, NDF and ash contents by the NIRS method (Landau et al., 2004, 2005). Quality data were analysed with an ANOVA model that included Year, Period, Management system (C, E and L) and SR effects and the interactions between them (SAS, 2002).

\section{RESULTS}

Significant differences in digestibility, protein, ADF and NDF of herbage were found between periods $(\mathrm{P}<0.0001)$, years $(\mathrm{P}<0.0001-0.0163)$ and the interactions between them $(\mathrm{P}<0.0001)$ (Table 1). Generally, herbage quality

Table 1. Analysis of variance of herbage quality over the period 2003-2005

\begin{tabular}{lccccc}
\hline & Protein & Digestibility & ADF & NDF & Ash \\
\hline Period & $<0.0001$ & $<0.0001$ & $<0.0001$ & $<0.0001$ & $<0.0001$ \\
Management & 0.0200 & 0.0381 & 0.0276 & 0.0215 & NS \\
Stocking rate & 0.0414 & NS & NS & 0.0460 & NS \\
Year & $<0.0001$ & 0.0003 & $<0.0001$ & 0.0136 & 0.0163 \\
Year $\times$ period & $<0.0001$ & $<0.0001$ & $<0.0001$ & $<0.0001$ & $<0.0001$ \\
Year $\times$ management & NS & NS & 0.0069 & NS & NS \\
Period $\times$ management & 0.0050 & 0.0011 & 0.0154 & 0.0060 & NS \\
Year $\times$ period $\times$ management & $<0.0001$ & NS & NS & NS & NS \\
\hline
\end{tabular}

decreased from the beginning of the grazing season (January-February), when vegetation was young, towards the end of the growing season (April) as it matured. During the summer (June to August) the herbage was dry and of relatively low quality. These changes in herbage quality are shown by the decrease of digestibility and protein content and the increase of ADF and NDF (Figure 1). Because the growing season is relatively short (five months), quality of herbage changes rapidly and differences found in herbage quality between years is probably a consequence of different phenological states of the sampled vegetation between years.

Grazing management system had significant effects on herbage quality (Figure 1 ), with differences occurring mostly during the green season. The quality of herbage in the $\mathrm{C}$ and $\mathrm{E}$ treatments was higher than that of the $\mathrm{L}$ treatment. The greatest difference was found during April at the height of the green growing season. On the whole, stocking rate had a relatively minor effect on herbage quality (Table 1$)$. A relatively high content of ash $(\sim 15 \%)$ was found during mid winter (January-February) compared to the rest of the grazing season (April September) $(\sim 12 \%)$. 

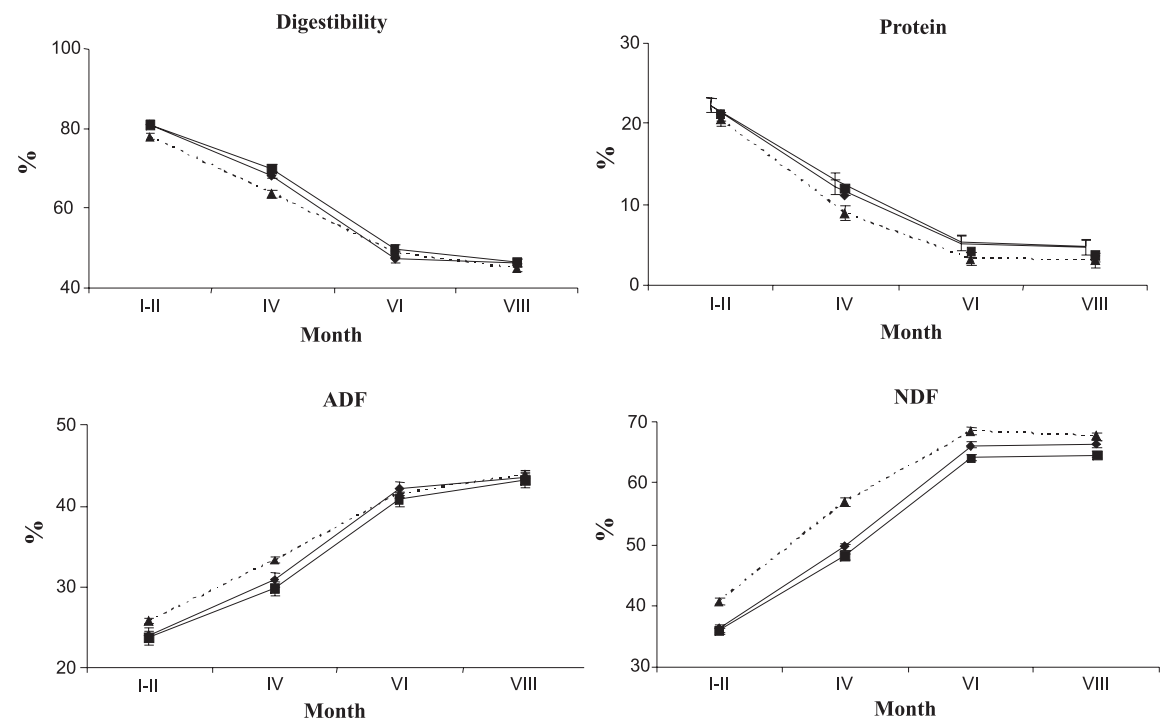

Figure 1. Digestibility, protein, ADF and NDF contents of herbaceous vegetation during the grazing season under continuous $(\diamond)$, early $(\boldsymbol{\square})$ and late $(\boldsymbol{\Delta})$ grazing management over the period 20032005

\section{DISCUSSION}

Forage quality in Mediterranean rangelands varies between periods of the year. In this study as well, a decrease in herbage quality between the beginning and the end of the growing season was found. In addition it was shown that herbage quality was affected by grazing management: herbage quality was higher for early and continuous grazing compared to late grazing. In another study (Sternberg et al., 2000), conducted on a Mediterranean herbaceous community rangeland, vegetation response to grazing management was tested. A reduction in cover of tall grasses was correlated with an increase in cover of prostrate annual legumes and less palatable groups such as annual and perennial thistles, crucifers and forbs. These differences in herbage composition and quality need to be taken into account in decisions taken in order to improve cattle management systems. As herbage quality is lower when vegetation matures, continuous or early grazing is important to maintain younger herbage with a relatively higher digestibility and protein content and lower ADF and NDF. In any case, because forage quality is low during the hot and dry season, moderate supplementation is needed during that period. 


\section{REFERENCES}

Gutman M., Holzer Z., Baram H., Noy-Meir I., Seligman N.G., 1999. Heavy stocking and earlyseason deferment of grazing on Mediterranean-type grassland. J. Range Manage. 52, 590-539

Gutman M., Holzer Z., Seligman N.G., Noy-Meir I., 1990. Stocking density and production of a supplemented beef herd grazing yearlong on Mediterranean grassland. J. Range Manage. 43, 535-599

Gutman M., Seligman N.G., 1979. Grazing management of Mediterranean foothill range in the upper Jordan river valley. J. Range Manage. 32, 86-92

Landau S., Dvash L., Decandia M., Cabiddu A., Shapiro F., Molle J., Silanikove N., 2004. Determination of polyethylene glycol-binding to browse foliage, as an assay of tannin, by nearinfrared reflectance spectroscopy. J. Agr. Food Chem. 52, 638-642

Landau S., Glasser T., Dvash L., 2005. Monitoring nutrition in small ruminants with the aid of near infrared reflectance spectroscopy (NIRS) technology: A review. Small Ruminant Res. 59, 251263

SAS, 2002. JMP Statistics and Graphics Guide, Version 5. SAS Institute. Cary, NC

Seligman N.G., Gutman M., Holzer Z., Noy-Meir I., Baram H., 1989. Stocking density of cattle and herbage production on Mediterranean grassland. J. Agr. Sci. 113, 51-58

Sternberg M., Gutman M., Perevolotsky A., Ungar E.D., Kigel J., 2000. Vegetation response to grazing management in a Mediterranean herbaceous community: a functional group approach. J. Appl. Ecol. 37, 1-15

Zohary M., 1973. Geobotanical Foundations of the Middle East. Gustav Fischer Verlag, Stuttgart (Germany) and Swets and Zeitlinger, Amsterdam (The Netherlands) 